\title{
PECULIARITIES OF COPING STRATEGIES IN THE MILITARY SERVANTS OF THE ARMED FORCES OF UKRAINE DURING DECOMPRESSION
}

У статmі розглянуто види копінг-стратегій, які використовуються військовослужбовиями підрозділів Збройних Сил України для боротьби зі стресовими ситуаціями. Сучасні види бойових дій висувають вимоги, які часто перевищують можливості та ресурси військових. Це формує потребу в особливому типі особистості, а саме стійкої, соціально активної, з високим рівнем саморегуляції та здатністю протистояти тиску з боку несприятливих фракторів, яка здатна правильно вибирати стратегію боротьби з стресом. Копінг-стратегіі являють собою важливий фрактор, який допомагає швидко і продуктивно подолати наслідки бойових дій, зокрема пережитий стрес і травми. Викладаються теоретичн основи дослідження, а саме роботи зарубіжних та вітчизняних учених, які займалися вивченням поняття копінг-стратегій у людей, що мають професії з підвищеним ризиком для життя, зокрема військових. Проведене автором опитування військовослужбовців Повітряних Сил, Сухопутних військ Збройних Сил України щодо основних видів копінг-стратегій, якими вони користуються задля подолання й опрацювання негативного досвіду, є частиною діагностичного комплексу, що проводиться після виведення підрозділів з Операції Об'єднаних Сил (ОоС). Важливим аспектом є те, що до участі залучені особи, які тривалий час перебували в зоні проведення бойових дій на Сході України і знаходяться на етапі декомпресії. Головна увага приділяється дезадаптивним та адаптивним варіантам кожного виду копінгу. Обговорюються варіативність проявів кожної копінг-стратегіі, особливості прояву в поведіниі та життєдіяльності, відносинах з колегами по службі, ставлення до роботи в групі та психологів. Отримані результати можуть бути підґрунтям для створення психокорекційноі програми роботи з бойовим стресом для діючих військовослужбовців Збройних Сил України, які періодично знаходяться на ротаціях в зоні ООС.

Ключові слова: копінг-стратегії, військовослужбовиі, дезадаптивний копінг, адап- тивний копінг, конорронтація, дистанціювання, самоконтроль, пошук соціально підтримки, прийняття відповідальності, втеча (уникнення), планування рішення, позитивна переоцінка

The article considers the types of coping strategies used by servicemen of units of the Armed Forces of Ukraine to combat stressful situations. Modern types of combat are requirements that often exceed the capabilities and resources of the military. This, in turn, creates a need for a special type of personality - stable, socially active, with a high level of self-regulation and the ability to withstand pressure from adverse factors, which is able to choose the right strategy to deal with stress. Coping strategies are an important factor that helps quickly and productively overcome the consequences of hostilities, including stress and trauma. There are present the theoretical foundations of the study - the work of foreign and domestic scientists who studied the concept of coping strategies in people with occupations at high risk to life, including the military. The author's survey of servicemen of the Air Force, Land Forces of the Armed Forces of Ukraine on the main types of coping strategies they use to overcome and process negative experiences is part of the diagnostic complex, which is carried out after the withdrawal of units from Operation Allied Forces. An important aspect is that persons who have been in the combat zone in eastern Ukraine for a long time and are at the stage of decompression are involved. The main attention is paid to maladaptive and adaptive variants of each type of coping. The variability of manifestations of each coping strategy, features of manifestation in behavior and vital activity, relations with colleagues, attitude to work in group and psychologists are discussed. The obtained results can be the basis for the creation of a psycho-correctional program of work with combat stress for active servicemen of the Armed Forces of Ukraine, who are periodically on rotations in the combat zone. Key words: coping strategies, military, maladaptive coping, adaptive coping, confrontation, distancing, self-control, social support, responsibility, escape (avoidance), decision planning, positive reassessment. психології

Постановка проблеми. Нині в психології актуальними $€$ дослідження, спрямовані на визначення особливостей поведінки особистості у складних, екстремальних умовах. Питання щодо стратегій діяльності та способів управління неоднозначними ситуаціями в житті постало в психології ще у XX столітті. В умовах ведення гібридної війни питання психологічного здоров'я і його відновлення стає дуже важливим. Перебуваючи під постійним психологічним тиском, військовослужбовці піддаються значному впливу бойового стресу, що призводить до порушення психологічного гомеостазу особистості. Як боротися з наслідками стресу, які методи і способи подолання застосовувати - ключове питання, на яке сьогодні намагаються знайти відповідь військові психологи. Використання адаптивних варіантів копінг-стратегій $є$ провідним аспектом для вирішення цієї проблеми.

Аналіз останніх досліджень і публікацій. Поняття копінгу вперше з'явилось у 1962 році. Тоді зарубіжний дослідник Л. Мерфі застосував цей термін під час вивчення поведінки 
дітей, які в цей період додали кризи розвитку. До них належали активні зусилля, спрямовані на оволодіння проблемою, що фактично було підструктурою особистісного захисту.

Однак справжніми авторами поняття копінг-стратегій вважаються іноземні науковці Р. Лазарус та С. Фолкман. У 1966 році саме Р. Лазарус у своїй книзі «Психологічний стрес і процес співпадіння з ним» [11, с. 144-157] звернувся до копінгу задля опису усвідомлених стратегій боротьби зі стресом та іншими подіями, які викликають тривогу. Було визначено, що індивіди оцінюють для себе величину потенційного стресора. При цьому вони складають оцінку власних ресурсів. Так, копінги стали включати реакцію на повсякденні стресові ситуації. Р. Лазарус та С. Фолкман подають таке визначення копінг-стратегій, яке вперше було використане в транзактній моделі стресу: це постійно змінні когнітивні та поведінкові способи подолання специфічних зовнішніх і внутрішніх вимог, які оцінюються індивідом як значні чи такі, що перевищують його можливості [11, с. 144-157].

Сьогодні визначення значно спрощене. Під копінгами розуміють усвідомлені прийомі, які використовує людина в складних ситуаціях, станах та умовах. Це всі прояви регуляції емоційного стану, що включають мимовільні процеси, обумовлені відмінностями в темпераменті та поведінці. Р. Лазарус визначив, що копінги загалом $є$ змінними, лише стійкі патерни формують копінг-стратегії або особистісні стилі [10, с. 22-46].

Своє тлумачення цього поняття представили також вітчизняні вчені. Зокрема, А. Маклаков розглядав копінг-стратегії в рамках концепції життєвості в психології. Він вважає, що копінг-стратегії $€$ адаптаційним потенціалом людини [4, с. 34-56].

Вітчизняний дослідник Ф. Василюк вважає, що індивід може посилити критичну ситуацію через переживання, які виступають формою діяльності, що спрямована на відновлення психологічної рівноваги. Таким чином, переживання можна розглядати як один із внутрішніх механізмів копінг-стратегій [5, с. 44-62].

Отже, необхідність вибору копінг-стратегій з'являється у кризових ситуаціях і покликана знизити психологічне напруження й тривожність, інтенсивність яких обумовлена щонайменше двома обставинами, а саме особистісними, суб'єктивними факторами і реальною ситуацією. Під суб'єктивним фактором слід розуміти особистісні характеристики, якими визначається інтенсивність психологічного дискомфорту. Індивідуальні реакції на психологічний дискомфорт можуть бути неусвідомленими з огляду на те, що мають досвід повторення, випадають з-під свідомого контролю. Більш того, одна й та ж ситуація викликає у різних людей психологічне потрясіння різної інтенсивності, що обумовлено такими властивостями особистості, як самооцінка, темперамент [10, с. 99].

Існує досить велика кількість класифікацій копінг-стратегій. Найперша була розроблена Р. Лазарусом та С. Фолкманом і включала такі види копінгів:

- спрямованість на оцінку (виникає в ситуації, коли індивід змінює свою позицію щодо виниклого запитання або відсторонюється від проблеми; відбувається це через страх неприйняття оточуючими власних цілей та цінностей і, як наслідок, негативної оцінки від них);

- спрямованість на проблему (використовується для з'ясування причин цієї проблеми; для цього проводяться пошук інформації і засвоєння нових навиків);

- спрямованість на емоції (припускає ї стримування, відволікання від них, контроль над неприємними почуттями, а також регулярне використання прийомів розслаблення).

Пізніше цю класифікацію доповнив та вдосконалив зарубіжний учений Дж. Вейлант. На його думку, також існує такі три види копінг-стратегій:

- пошук соціальної підтримки (ця стратегія пов'язана з отриманням допомоги і підтримки від інших людей);

- копінги, що використовуються в складний ситуаціях (сюди належать стратегії, які виділили Р. Лазарус та С. Фолкман);

- мимовільні психічні механізми, які змінюють внутрішню та зовнішню реальність задля зменшення стресу [9, с. 46-75].

Ще одну класифікацію представила група вченихТ. Крюкова, Е. Куфтяк, М. Замишляєва, які адаптували методику визначення копінг-стратегій. Вони пропонують такі види копінгів:

- конфронтаційний (агресивні зусилля для зміни ситуації, передбачення певного ступеня ворожості і готовності до ризику);

- дистанціювання (когнітивні зусилля відокремитися від ситуації і зменшити її значимість);

- самоконтроль (зусилля задля регуляції своїх почуттів і дій; включає пошук соціальної підтримки та зусилля в пошуку інформаційної, дієвої та емоційної підтримки);

- прийняття відповідальності (визнання своєї ролі в проблемі і спроби її вирішити);

- втеча/уникнення (уявне прагнення і поведінкові зусилля спрямовані на втечу від проблеми чи ї̈ уникнення);

- планування вирішення проблеми (довільні проблемно-фокусуючі зусилля зі зміни ситуації, включають аналітичний підхід до питання);

- позитивна переоцінка (зусилля для створення позитивного значення з фокусуванням на рості власної особистості, включає також релігійний вимір) [6, с. 21-34]. 
Отже, загалом варто відзначити, що більшість класифікацій копінг-стратегій побудована на базовій теорії Р. Лазаруса і С. Фолкмана, що являє собою основні види копінгів.

Постановка завдання. Метою статті $€$ висвітлення результатів дослідження вибору копінг-стратегій військовослужбовцями під час проходження періоду декомпресії.

Виклад основного матеріалу дослідження. Для діагностики копінг-стратегій у військовослужбовців під час декомпресії було використано опитувальник «Способи опановуючої поведінки» Р. Лазаруса і С. Фолкмана в адаптації Т. Крюкової, Е. Куфтяк, М. Замишляєвої. Методика проводилась у комплексі діагностичних процедур під час першого етапу декомпресії. Участь у дослідженні взяли 150 військовослужбовців різних підрозділів Повітряних Сил та Сухопутних військ Збройних Сил України. Отримані результати наведені в табл. 1.

3 табл. 1 можна відзначити, що найбільш вираженими дезадаптивними копінгами $€$ позитивна переоцінка та самоконтроль. 36\% військовослужбовців намагаються впоратися з стресовою ситуацією за рахунок позитивного переосмислення ситуації, однак вони починають недооцінювати дійсне вирішення ситуації. У бойових умовах це має негативний вплив, оскільки може поставити під загрозу життя не лише конкретного військового, але й цілого підрозділу, адже відбувається певний відрив від реальності, надання ситуації надмірної цінності як позитивного стимулу. При цьому негативний стрес починає розглядатися як позитивний момент, відбувається заперечення пережитої ситуації, як наслідок, блокування стресових спогадів, що в подаль- шому впливає на проходження декомпресії та унеможливлює психічне відновлення.

47\% військовослужбовців використовують цю стратегію в адаптивному варіанті. Позитивна оцінка складного психологічного досвіду допомагає опрацювати його і впоратися з негативними аспектами. Деякі військовослужбовці намагають використати пережиту стресову ситуацію як ресурс у боротьбі з противником, особливо під час психологічних атак. У $17 \%$ ця стратегія виражена в граничному стані (табл. 1), тобто вони намагають адекватно оцінити ситуацію, проте втрачають раціональність суджень і недооцінюють важливі аспекти стресового досвіду.

34\% військовослужбовців мають дезадаптивний варіант стратегії самоконтролю. Вони надмірно зациклені на фокусуванні на всьому, що їх оточує. Під час переживання бойового стресу надконтроль може призвести до розвитку нав'язливих станів, а в подальшому до виникнення неврозів. Таким військовослужбовцям важко виражати свої емоції і почуття. Відбувається загальне блокування емоційної сфери, що супроводжується виникненням фізіологічних порушень як наслідку психічного перевантаження. Їм важко визначати, що вони пережили стрес, адже надмірна вимогливість до себе не дає змогу виражати справжні переживання. Більш того, будь-які спроби допомоги від психологів сприймаються вороже. Відбувається суцільне заперечення будь-яких емоцій, оскільки вони вважаються проявом слабкості. У такому разі заходи декомпресії зазвичай не допомагають перевести цей копінг в адаптивний, такі військовослужбовці потребують додаткової психологічної реабілітації.

\section{Результати діагностики копінг-стратегій військовослужбовців під час проведення декомпресії}

\begin{tabular}{|c|c|c|c|c|c|c|c|}
\hline \multirow[t]{2}{*}{ № } & \multirow[t]{2}{*}{ Назва копінг-стратегії } & \multicolumn{2}{|c|}{\begin{tabular}{|l|} 
Високий рівень \\
(дезадаптація)
\end{tabular}} & \multicolumn{2}{|c|}{$\begin{array}{l}\text { Середній рівень } \\
\text { (граничний стан) }\end{array}$} & \multicolumn{2}{|c|}{$\begin{array}{l}\text { Низький рівень } \\
\text { (адаптивний копінг) }\end{array}$} \\
\hline & & 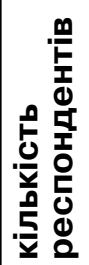 & 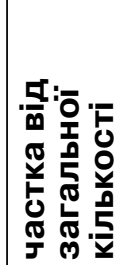 & 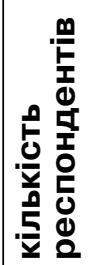 & 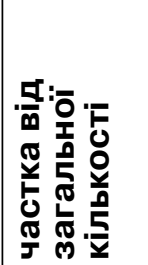 & 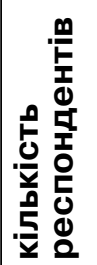 & 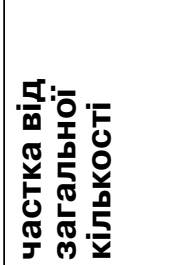 \\
\hline 1 & Конфронтація & 10 & $7 \%$ & 59 & $39 \%$ & 81 & $54 \%$ \\
\hline 2 & Дистанціювання & 25 & $17 \%$ & 23 & $15 \%$ & 102 & $68 \%$ \\
\hline 3 & Самоконтроль & 51 & $34 \%$ & 12 & $8 \%$ & 87 & $58 \%$ \\
\hline 4 & Пошук соціальної підтримки & 5 & $5 \%$ & 74 & $49 \%$ & 71 & $47 \%$ \\
\hline 5 & Прийняття відповідальності & 13 & $13 \%$ & 90 & $60 \%$ & 47 & $31 \%$ \\
\hline 6 & Втеча (уникнення) & 39 & $26 \%$ & 14 & $9 \%$ & 97 & $65 \%$ \\
\hline 7 & Планування рішення & 11 & $8 \%$ & 74 & $49 \%$ & 65 & $43 \%$ \\
\hline 8 & Позитивна переоцінка & 55 & $36 \%$ & 25 & $17 \%$ & 70 & $47 \%$ \\
\hline
\end{tabular}

Таблиця 1 
Як видно з табл. 1, 58\% військовослужбовців використовують самоконтроль як адаптивну стратегію боротьби зі стресом. Вони намагаються раціонально підходити до розуміння пережитого, дати адекватну оцінку власним діям і дійти висновків, які можна використати в подальшому. Під час проведення дебрифінгу вони найбільш точно дають оцінку ситуації, описують їі без зайвих емоційних імпульсів. Лише у $8 \%$ ця стратегія має граничний стан. Такі респонденти не завжди можуть адекватно оцінити все, що відбувається. Характерними для них $є$ короткочасні імпульсивні, емоційні реакції. Варто відзначити, що найменш вираженою в дезадаптивному варіанті $€$ копінг-стратегія конфронтації та планування рішення (7\% і 8\% відповідно). Отже, такі військовослужбовці поводяться недостатньо раціонально та цілеспрямовано, досить імпульсивні, ворожі та конфліктні. Також вони надмірно раціональні, беземоційні. Важливим аспектом $€$ те, що навіть невелика кількість осіб з дезадаптивною стратегію конфронтації може порушити діяльність цілого підрозділу через розпалювання конфліктів, постійні зриви та недовіру до оточення. Також такі військовослужбовці блокують роботу психологів і заважають працювати групі загалом. Зокрема, під час проведення дебрифінгу, з якого починається декомпресія, вони поводяться дуже замкнуто, не беруть участі у обговоренні та не виражають жодних емоцій, почуттів, що є необхідними як підтримка для інших.

При цьому 54\% військовослужбовців, а це майже більшаполовинадосліджуваної вибірки, використовують конфронтацію як адаптивну копінг-стратегію (табл. 1). Вони намагаються впоратись зі стресовою ситуацією за рахунок цілеспрямованої поведінкової активності. Зниження напруги відбувається шляхом реагування на накопичені негативні переживання. Однак використання цього копінгу потребує контролю і супроводу з боку психологів. Важливо не допустити імпульсивних спалахів ворожості, люті. Завданням психологів є допомога відпрацювати негативний досвід за допомогою наявного ресурсу задля підтримання внутрішнього прагнення протистояти труднощам. Такі військовослужбовці мають перевагу, оскільки вони вміють відстоювати власні інтереси і справляються з тривогою самостійно, не придушуючи іï, а відпрацьовуючи.

Найбільш вираженим адаптивним копінгом $€$ дистанціювання. 102 військовослужбовці використовують цю стратегію як домінантну. Вони намагаються переосмислити стресову ситуацію та знизити її значимість. Неодноразовопсихологивідзначали, щодистанціювання в умовах тривалого ведення війни $є$ засобом збереження психічного гомеостазу, оскільки суб'єктивне зниження емоційного включення в ситуацію забезпечує можливість раціонально оцінювати ситуацію, не піддаватися психічному тиску, зокрема, з боку противника. До того ж ця стратегія часто використовується задля зниження емоційних переживань, пов'язаних зі втратами у підрозділі. В такий спосіб військовослужбовці намагаються тримати свій емоційний стан під контролем для збереження тверезої оцінки ситуації, від якої залежить життя. Проте $17 \%$ респондентів мають дезадаптивний варіант цієї стратегії. Такі військовослужбовці відокремлюються від групи, їм важко включатися в атмосферу підрозділу, оскільки вони вважають їі напруженою і важкою для власного психічного здоров'я. Ще одним вираженим в адаптивному варіанті $\epsilon$ стратегія втечі (уникнення), її використовують 97 військовослужбовців. Під час тривалого перебування в умовах стресу виникає бажання втекти від ситуації. Військовослужбовці часто використовують цей копінг задля зниження емоційної напруги у стресових ситуаціях. Втеча не $€$ досить продуктивною стратегією, оскільки тягне за собою накопичення негативних переживань. Під час роботи з такими військовослужбовцями варто спрямувати їх на вибір більш адаптивних варіантів копінг-стратегій, оскільки постійне використання уникнення призводить до відчуженості, поверхневості суджень та недостатньої оцінки ситуації. 26\% військовослужбовців використовують стратегію уникнення, проте в дезадаптивному варіанті. Стратегія прийняття відповідальності у $60 \%$ респондентів представлена в граничному стані. У них відзначається надмірна самокритика, надвідповідальність. У разі втрат у підрозділі такі військовослужбовці починають звинувачувати себе в цьому, постійно аналізують свої дії і намагаються знайти причину, що привела до цього. Як наслідок, формується почуття провини, що повністю пригнічує позитивне мислення та формує предикти розвитку депресивних станів. 31\% військовослужбовців має адаптивний варіант цієї стратегії. Військовослужбовці адекватно оцінюють свою роль у ситуації, не проявляють зайвої активності. у $13 \%$ респондентів стратегія прийняття відповідальності виражена в дезадаптивному стані. Вони вважають, що несуть відповідальність за все, що відбувається в їхньому оточенні, постійно себе критикують і оцінюють власні дії лише негативно.

Пошук соціальної підтримки в адаптивному варіанті представлений у $47 \%$ респондентів, тобто військовослужбовці намагаються максимально використати зовнішні ресурси для вирішення стресової ситуації. Під час вжиття заходів декомпресії ця стратегія вважається однією з найпродуктивніших, оскільки військові готові до роботи з психологами, легко працюють у групі, розкриваються під час 
дебрифінгу, підтримують один одного. Варто відзначити, що в граничному стані цю стратегію використовують 49\%. Такі досліджувані надмірно прив'язуються до соціального оточення й очікують занадто великої віддачі і зусиль від оточення, що часто не виправдовується і стає причиною розвитку депресивних станів. Завдання психологів полягає в тому, щоби правильно розставити пріоритети і не перекладати відповідальність за власні дії на інших. У 5\% військовослужбовців наявний дезадаптивний варіант цієї стратегії, що свідчить про значно завищені очікування допомоги від оточення.

Висновки 3 проведеного дослідження. Загалом варто відзначити, що всі досліджені копінги використовуються в цій вибірці респондентів для боротьби зі стресом. Деякі стратегії проявляються в дезадаптивному варіанті (втеча, самоконтроль, позитивна переоцінка), проте більшість використовується в адаптивному, що забезпечує продуктивне проходження психологічних заходів декомпресії і сприяє відновленню як кожного військовослужбовця окремо, так і підрозділів загалом. Визначення провідних копінг-стратегій $є$ важливим аспектом під час створення програм декомпресії та реабілітації військовослужбовців, забезпечує розроблення ефективних моделей боротьби зі стресом, які будуть адаптовані до кожного з урахуванням його адаптивних варіантів копінгів. Так, у подальшому це дасть змогу напрацювати відповідну схему відновлення психіки військовослужбовців та зменшити кількість небойових втрат, пов'язаних із психічними порушеннями, які розвиваються внаслідок бойового стресу.

Отже, результати нашого дослідження підкреслюють важливість дослідження копінг-стратегій у контексті вжиття заходів відновлення психічного здоров'я військовослужбовців, тому перспективою подальших досліджень буде розроблення психокорекційної програми для роботи з бойовим стресом за допомогою адаптивних копінгів.

\section{ЛITEPATУРA:}

1. Бітехтина Л. Готовність до дій в екстремальних ситуаціях військових. Питання психології. 2005. № 11. C. 41-47.

2. Бодров В. Психология профессиональной деятельности : учебное пособие. Москва : Институт психологи РАН, 2006. 623 с.

3. Большая энциклопедия психологических тестов. Москва : Эксмо, 2005. 416 с.

4. Гуревич П. Психологія надзвичайних ситуацій : навчальний посібник. Москва : ЮНІТ-Дана, 2007. 494 c.

5. Журавльов О. Психологічні чинники фрізичного і психічного здоров'я. Безпека Євразії. 2004. № 1. C. 44-62.

6. Крюкова Т. Психологія поведінки. Москва : Просвітництво, 2004. 148 с.

7. Куликов Л. Психогігієна особистості: Питання психологічної стійкості і психопрофілактики. Санкт-Петербург : Нева, 2004. 218 с.

8. Куликов Л. Теорія стресу і психофрізіологічні дослідження: Емоційний стрес. Ленінград : Наука, 1989. $241 \mathrm{c}$.

9. Купріянов Р., Кузьмина Ю Психодиагностика стресса : практикум. Казань : КНИТУ, 2012. 212 с.

10. ПОЛІт. Сучасні проблеми науки. Гуманітарні науки : тези доповідей XV Міжнародної науково-практичної консреренції молодих учених, м. Київ, 8-9 квітня 2015 року, НАУ / ред. М. Кулик та ін. Київ : HAY, 2015. $432 \mathrm{c}$.

11. Lazarus R., Folkman S. Stress appraisal and coping. N.Y. : Springer, 1984. P. 22-46.

12. Lazarus R.S. Cognitive and coping processes in emotion. Stress and coping. N.Y. : Columbia Univ. press, 1997. P. 144-157. 